\title{
Modes Of Funding Nigerian Universities And The Implications On Performance
}

\author{
Christiana, O. Ogbogu, PhD, Obafemi Awolowo University, Nigeria
}

\begin{abstract}
This paper examined the modes of funding Nigerian universities with a view to assessing their adequacy and effectiveness. The implications of the mechanisms of funding on university performance were investigated. The history of university funding in Nigeria was explored in order to determine the causes of shift in financing the system since 1948 when the first university was established. The paper revealed that the costs of financing universities including: costs of teaching, research and administration, cost of accommodating increased enrollments, expenses of student maintenance, payment of staff entitlement/salaries and maintenance of facilities are increasing in excess of the corresponding rates of available revenues. The divergence in the trajectories of total university educational cost, the total available revenue and government subvention has led to capacity constraints of universities. This is evident in poor quality of teaching and research, poor conditions of work and insufficient attention to staff development, amongst others. The study found that the changing patterns in funding of universities are responses to the social and economic depression of the country, globalization, country's desire to be integrated into the modern knowledge economy and increased enrollment without adequate planning. Consequently, the African political economy model was used in explaining the financial state of Nigerian universities, while the theory of human capital was used to support the arguments in favour of multiple forms of cost-sharing. These include private support from parents/students and donors since education is both a government and private investment. The study concluded that part of the solutions to cost-revenue squeeze in Nigerian universities is the development of proactive mechanisms that facilitate both the identification of multiple sources of funding as well as their optimal utilization in order to maintain financial balance and enhance performance. The Resource-Based Model for sustaining financing of universities was thus recommended.
\end{abstract}

Keywords: Funding; Finance; Performance; Universities; Nigeria

\section{INTRODUCTION}

O niversities all over the world are regarded as engines of economic and sustainable national development. They transmit knowledge and train the human minds (Johnstone, 2005). In Nigeria, the universities are veritable tools for the realization of national development; the development of cultured citizens and the promotion of basic research. University education is therefore the most powerful and critical success factor for individuals and the society (Aina, 2007).The Nigerian university system has grown astronomically in size and has undergone deep transformation since its inception over 60years ago. It is however unfortunate that their ability to act as engines of growth and development is being challenged by the long-standing problem of inadequate funding. For universities to effectively perform their roles there must be adequate funding. Nigerian government's priority to universities in terms of funding has declined and this has limited the ability of the universities to effectively and efficiently perform their duties, particularly the traditional roles of teaching and research. (Bamiro and Adedeji, 2010).

The problem of underfunding of Nigerian universities is a consequence of the expansion of the system in response to the growing demand for university education and the intensifying needs of modern economy driven by knowledge, without an increase in the corresponding rates of available resources. The government of Nigeria for a 
long time remained the sole financier of universities, but due to economic depression and a drop in oil receipts, the country now faces tight budget constraints. Consequently, the federal government has made it mandatory for federal universities to generate 10percent of their total income, while the government provides the remaining 90percent. In response to this, Nigerian federal universities have embarked on income generating activities.

There is need for a transformation within the university system, so that the challenges of chronic under funding can be addressed. It is against this background that this paper examined the modes of funding federal universities in Nigeria, with a view to assessing their adequacy and effectiveness. It also identified the implications of the mechanisms of funding on university performance and explored the history of university funding in order to determine the causes of the shift in financing the system since its inception. Consequently, alternative modes of funding the system were proffered. This study is timely because it would serve as a framework for designing policy on sustainable financing of Nigerian universities.

\section{THE HISTORY OF UNIVERSITY FUNDING IN NIGERIA}

The Nigerian University System commenced in 1948 with the establishment of University College Ibadan which was then an affiliate of the University of London. The university being the only one in the country was adequately funded in all aspects of teaching and research by both the Nigerian and British governments. Between 1948 and 1954, the federal government's capital expenditure on the university college Ibadan, was over £3.6 million and the total recurrent expenditure over the same period amounted to £112, 269 (NUC, 2003).

Five additional universities known as the first generation universities were established in Nigeria after independence, between 1960 and 1973.The universities performed well and were adequately funded by the government. At that time, tuition fees were charged according to various programmes, the federal government released subvention to the universities regularly, and scholarships/bursaries were made available to poor student (Akintoye, 2008). Okebukola (2002) noted that there was no substantial difference between the amount requested by the universities and the amount received from the government. In fact, there were years in which the amount received was slightly higher than the amount requested for. For instance, Ejiogu (1986) affirmed that the annual federal grants to the five first generation universities in the country at that time rose from $£ 2.56$ million in 1963/1964 to $£ 5.9$ million in 1968/1969. Also, between 1960 and 1969, the universities of Ibadan and Lagos received 100percent subsidies from the federal government of Nigeria. Apart from government subsidy, other sources of funds for all the universities were occasional grants for research, individual donations and endowments (Fafunwa, 1971).

The financial problems of Nigerian universities commenced after the establishment of the seven universities of technology known as the second generation universities, between 1975 and 1980, without a corresponding increase in government subvention to the existing universities. The sudden onset of underfunding of the universities at that time was linked to the depression in the country's economy evident in the downward trend in oil and non-oil exports, with rising import bills. The country suffered deficits in balance of payments and lost international credit worthiness (Odebiyi and Aina, 1999).Furthermore, the sharp deterioration in university funding was accentuated by the fact that tuition fees was abolished, boarding fees was pegged and government remained the only source of funds for the universities.

The third generation universities (eleven in number) were established between 1980 and 1990, while the fourth generation universities consisting mainly of private universities were established in 1991 and they have continuously increased in number (Ekundayo and Ajayi, 2009).The liberalization of the establishment of universities was not just to facilitate access but it was a response to the country's desire to be integrated into the modern knowledge economy. This development increased enrollment, but without adequate planning. There has been a downward trend in the funding of universities in the country since then such that funds released to them by government are always inadequate (Adeniyi, 2008). For example, government's grants dropped from N148.9 million in 1977 to N85 million in 1978. The local incomes also dropped from N24million in 1977 to N22.9million in 1978.Most of the capital projects at that time were abandoned and there was considerable deterioration of physical facilities. Currently, the Nigerian government controls universities through the National Universities Commission which among other functions allocates funds to Federal Universities and also prescribes the spending formula, (See Table 1 below). 


\section{MODES OF FUNDING NIGERIAN UNIVERSITIES}

Funding universities throughout the world has witnessed dramatic changes in the last decades of the $20^{\text {th }}$ and the first decade of the $21^{\text {st }}$ centuries. These changes are responses to a worldwide phenomenon of rising cost of university education in excess of the corresponding rates of increase of available revenues. In order to cope with government funding reductions, universities worldwide now generate additional sources of funds (Johnstone, 2005).

In Nigeria funding shortfalls have been the norm for many years as enrollments have increased more quickly than the government's capacity to maintain its proportional financial support. Because government funding is insufficient to maintain institutional performance in teaching and research, Nigerian universities, just like other universities elsewhere in the world have sought to supplement their public funding with locally generated incomes. The various sources of funding Nigerian federal universities are presented below:

\section{Government Subvention/Allocation}

Government is the major source of funds for federal universities in Nigeria. It provides 90percent of the total income disbursed through the Nigerian Universities Commission (a buffer organization that assists the government in coordinating the affairs of the universities); the remaining 10percent is locally generated by each university. Although a lion share of the revenue comes from the government, compared to money generated internally, there is a notable fluctuation in the amount the universities request from the government and the amount that is released to them annually as evident in Table 1 below. According to Adeniyi (2008), the subvention received by the universities from the federal government is inadequate in meeting their financial demands. This is because the universities are affected by the unstable economic conditions as well as other government policies on the university finances such as embargo on payment of tuition in federal universities (Babalola, et al, 1996). Bamirio and Adedeji (2010) attribute this not just to social and economic depression of the country but also to the country's desire to be integrated into the modern knowledge economy with an increased enrollment without adequate planning. In view of this, Hartnett (2000) suggested that more creative and adaptable financing strategies are needed in order for Nigerian universities to offset the declining educational quality, resource use efficiency and learning effectiveness that now confronts them. Table I below shows government allocation of funds to the federal universities from 1990 to 2008.

Table 1: Funding of federal universities from 1990-2008

\begin{tabular}{|c|c|c|c|}
\hline Year & Budget $(\mathbf{N})$ & Appropriation $(\mathbf{N})$ & Released (N) \\
\hline 1990 & $1,216,601,329.00$ & $748,345,040.00$ & $734,770,950.00$ \\
\hline 1991 & $1,453,291,051.00$ & $779,342,391.00$ & $783,816,895.00$ \\
\hline 1992 & $3,653,212,945.00$ & $2,989,030,126.00$ & $2,985,237,346.00$ \\
\hline 1993 & $5,075,859,925.00$ & $4,532,229,830.00$ & $3,801,529,278.00$ \\
\hline 1994 & $7,342,861,713.00$ & $5,469,345,420.00$ & $4,370,880,770.00$ \\
\hline 1995 & $11,328,520,905.00$ & $6,392,648,852.00$ & $6,056,784,806.00$ \\
\hline 1996 & $12,442,699,358.00$ & $7,535,594,539.00$ & $7,535,594,529.00$ \\
\hline 1997 & $15,820,155,501.00$ & $7,059,178,565.00$ & $5,348,173,942.00$ \\
\hline 1998 & $22,767,539,158.00$ & $8,196,511,292.00$ & $9,798,392,523.00$ \\
\hline 1999 & $40,884,109,125.00$ & $10,507,388,580.00$ & $11,831,930,271.98$ \\
\hline 2000 & $65,579,997,692.00$ & $33,788,940,311.00$ & $30,143,004,497.91$ \\
\hline 2001 & $68,911,759,219.11$ & $31,844,324,846.42$ & $32,646,410,861.00$ \\
\hline 2003 & $62,155,484,641.00$ & $33,778,450,500.00$ & $30,351,483,193.00$ \\
\hline 2004 & $78,762,123,727.00$ & $34,411,319,280.00$ & $34,203,050,936.33$ \\
\hline 2005 & $216,622,706,206.00$ & $53,024,557,482.61$ & $53,466,287,486.01$ \\
\hline 2006 & N/A & $62,215,631,536.00$ & $58,275,967,608.72$ \\
\hline 2007 & N/A & $82,376,685,198.00$ & $82,376,684,290.00$ \\
\hline 2008 & N/A & $90,565,259,337.00$ & $90,565,259,337.00$ \\
\hline N/A & $105,751,671,988.00$ & $105,751,671,988.00$ \\
\hline
\end{tabular}

Source: Adapted from National Universities Commission, Abuja. 


\section{Education Trust Fund (ETF)}

The Education Trust Fund (ETF) was established in 1993 to facilitate the execution of projects aimed at improving the quality of education in Nigeria. In order to generate sufficient funds the Act which established it imposed 2percent Education Tax on the assessable profit of all registered companies in Nigeria. Currently, the ETF is a major source of funding for the various institutions in the country particularly with the federal government directing the fund through a major policy that stimulates that it should assist universities in the commencement, completion and rehabilitation of capital projects embarked upon by them. It is also currently the source of special intervention to develop six Nigerian federal universities into world-class institutions by providing and upgrading the facilities for teaching, learning and research, and the development of the requisite human capital. It is the desire of the federal government that the selected universities will improve their ranking after the implementation of the various projects (Bamiro and Adedeji, 2010). Table 2 below shows ETF allocations to the various higher education institutions in Nigeria from 2001 to 2006.

Table 2: ETF Allocations to HEIs (N million) (2001 - 2006)

\begin{tabular}{|c|c|c|c|c|}
\hline Year & Universities & Polytechnic & Colleges of Education & Monotechnics \\
\hline 2001 & 1,794 & 968 & 1,116 & 345 \\
\hline 2002 & 3,244 & 1,643 & 1,743 & 448 \\
2003 & 1,441 & 635 & 679 & 290 \\
2004 & 1,516 & 61 & 740 & 285 \\
\hline 2005 & 2,025 & 1,658 & 1,259 & 348 \\
\hline 2006 & 45 & 1,122 & 1,240 & 649 \\
\hline Total & 10,064 & 6,085 & 6,776 & 2,365 \\
\hline
\end{tabular}

Source: Bamiro and Adedeji (2010)

\section{Internally Generated Revenue (IGR)}

In Nigeria, the federal government has compelled each university to generate at least 10percent of its total revenue. It is in response to this that the universities have expanded the scope of their internally generated revenue to include: student fees / levies, grants, private sector contributions (e.g. endowments, gifts and donations etc) commercial activities/consultancy and other diverse initiatives.

\section{Student Fees / Levies}

Although there is a general government embargo on payment of tuition fees for undergraduate programmes, most of the universities have devised other methods of fee collection, for services such as accommodation in the halls of residence, sports, medical registration, departmental registration, library, examination, non-refundable admission deposits, etc. These fees vary in amount paid from one university to another. Student contributions according to Hartnett (2000) for the period 1986 - 1994 increased from 0.28 percent to 3.89percent of the total internally generated revenue. Also, between 1988 and 1998, the total locally generated income from students' fees in the universities increased from 4percent to 10percent. Currently, undergraduate student registered in the various federal universities pay between N30, $000(\$ 193.54)$ and N50, 000 (\$322) as fees, which is still relatively cheap (Bamiro and Adedeji, 2010).

In addition to fees, many non-degree/diploma courses have been introduced at exorbitant fees. For example, the Masters in Business Administration (MBA) programmes and the Computer Diploma courses in all federal universities among other programmes have recorded financial success. Saint et al (2003) indicated that over 80percent of the universities' internally generated revenue are derived mainly from fees for the different programmes. Although attempts by federal universities to increase levies have always met with stiff opposition by students, it still remains the major source of internal funds. 


\section{Grants}

Several foreign grants have aided and supported Nigerian universities' postgraduate study programmes and staff development. Some of the agencies that have supported Nigerian federal universities include: John, D and Catherine, T. MacArthur Foundation, Ford Foundation, World Health Organization (WHO), Carnegie foundation etc. For example, the MacArthur and Carnegie foundations have been supporting four universities in Nigeria since 2010 in the key areas of staff development and development of ICT infrastructure. The University of Ibadan was awarded a total of $\$ 6.4$ million between 2000 - 2007 and $\$ 3.1$ million to Bayero University, Kano for the period 2008 - 2010 by MacArthur and Carnegie Foundation respectively for various development projects (Bamiro and Adedeji 2010).

\section{Private Sector Contributions}

Contributions from the private sector to university education in Nigeria are limited to the endowments of prizes and professional chairs, gifts and voluntary donations (Ajayi and Alani, 1996). For example, the Petroleum Technology Development Fund (PTDF) established professional chairs in six universities to undertake research relevant to capacity building in the oil and gas industry. The institutions involved have been enjoying annual allocations ranging from N14million to N20million per institution in the recent past to support the chairs (Bamiro and Adedeji, 2010).Gifts and donations from the private sector are usually in the form of cash and physical structures given to the universities by individuals or groups. The Nigerian public has not however, imbibed the spirit of endowments to the universities, explicated in the usual general low response to calls for endowment to the universities.

\section{Commercial ventures}

Nigerian federal universities have embraced commercial ventures in response to government's mandate that each university must generate at least 10percent of its total revenue. The commercial ventures which are of different kinds include: consultancies, petrol stations, bookshops, publishing houses, schools, hotels etc. The margin of profits from the different ventures ranges between 4.7 million naira and 82.9 million naira annually from each university. The ventures which attract high profit margin are those offering professional services such as consultancy, distant learning programmes and hotel services. It is important to note that the University of Ibadan was the first to develop insights into commercial ventures, many of which were established in the 1970s.Generally, the profits made from these various ventures are ploughed back for expansion and for enhancing the working conditions of staff.

\section{THE IMPLICATIONS OF INADEQUATE FUNDING ON UNIVERSITY PERFORMANCE}

The problem of underfunding which is a major challenge confronting the Nigerian university system has had adverse effects on the performance of the universities. The Nigerian government finds it difficult to sufficiently fund her universities because of the growing enrollments without a corresponding impressive quality funding due to economic depression. There is no doubt that this has performance decreasing effects on both staff and students. For instance, Bamiro and Adedeji, (2010) indicated that the quality of teaching and research has fallen considerably because of lack of adequate teaching and research materials, coupled with overcrowded unconducive teaching and learning environment. They noted that the Nigerian government spends just 0.1 percent on research, while federal universities spend only 1.3 percent of their budgets on research. This has implications for development, because research constitutes a veritable catalyst for the economic advancement of nations and adequate funding is the propeller for research.

Furthermore, the effects of inadequate funding are evident in the fact that the physical facilities in respective universities are in a state of disrepair, several capital and research projects have been abandoned, laboratories and libraries are ill equipped, academic staff do not attend conferences regularly and there is a drastic reduction in the award of research grants and fellowships. Although, the National policy on education acknowledges the fact that adequate funding is a criterion for the success of any educational programme, Adeniyi (2008) however, noted that there is a general reduction in efficiency and productivity of universities because of dearth of funds. 
Yusuf (2010) added that the facility carrying capacity of the universities dropped from 78percent in 1979 to 39percent in 1999.The proportion of quality staff dropped from 91percent in 1979 to 63percent in 1999 and the factors that previously enhanced the performance of universities were negated.

Nigerian federal universities need to respond to the financial challenges that currently confront them by developing more creative and adaptable funding strategies to offset the likely risks of declining educational quality, resource use efficiency and learning effectiveness that now confronts them.

\section{ALTERNATIVE STRATEGIES FOR FUNDING NIGERIAN UNIVERSITIES}

Hartnett (2000) posits that when government funding becomes insufficient to maintain institutional performance, universities elsewhere in the world have sought to supplement their public funds with locally generated income. This is also true in Nigeria, but slow progress has been registered in this front. The political social and economic factors which currently have significant impact on the world economy necessitates that Nigerian university diversify the sources of education funding. In view of this, viable strategies for attaining economic survival and sustainable financing of Nigerian universities are posited below:

\section{Cost - Sharing Strategy}

Cost-sharing according to Johnstone (2005) is the diversification of revenue sources from heavy dependence on the government to being shared with parents and students. Cost-sharing is most associated with payment of tuition fees. Although several universities worldwide receive a great proportion of their income through student tuition, it remains the principal untapped source of funding in Nigerian universities.

In Nigeria, although student's contributions are made through charges for registration, examination, library, laboratory amongst others, tuition fees at the undergraduate level is yet to be tapped. This study advocates for the introduction of tuition fees at all levels of study in federal universities, but with in-built mechanisms such as soft loans for students (e.g. scholarships) which could reduce economic strain on the students and their parents in the face of the current economic crisis in the country. Nigeria should draw lessons from what obtains in the United States and other parts of the world as evident in Johnstone's (2008) study. He affirmed that tuition fees remain the most financially promising source of income for universities in the United States. If university education is government investment as well as private investment, then everyone should be involved in financing the full costs. Thus, cost-sharing is a more acceptable means of sufficiently funding universities to provide quality higher education for the growing numbers of Nigerian students.

\section{Revenue Supplementation Strategy}

Revenue supplementation strategy is a preferred route to financing viability of universities. It includes university entrepreneurship such as renting of university facilities as well as commercial marketing of research discoveries, university/industry collaboration, sale of faculty services, consultancy, introduction of specialized and marketable teaching and scholarship, establishment of guest houses, bookshops, petrol stations etc.

In Nigeria, some universities have expanded the scope of their commercial activities to include the introduction of specialized and marketable programmes (e.g. MBA Executive), establishment of bookshops, petrol stations, consultancy services etc. For example Obafemi Awolowo University, Ile-Ife established centres through which both the university and the industries can collaborate. Examples are:

- $\quad$ Centre for Industrial Research and Development (which services medium and small scale research).

- Technological Planning and Development unit (which provides the needed technological know-how to large, medium and small scale industries in the country).

- $\quad$ Drug Research Unit, Faculty of Pharmacy (produces and markets drugs locally) etc.

- These centres and units provide the productive sector with the needed expertise. Sometimes however, the performance of these various commercial ventures does not justify their existence. Therefore, the universities need to closely monitor these ventures to ensure accountability and profitability. Every 
Nigerian university needs to aggressively embark on strategic fund raising programmes and diversified ventures of increased internally generated revenue for resilience and sustainability. This study therefore, advocates for a more university - productive sector linkages, because the research outputs further benefits the industries.

\section{THEORETICAL ISSUES AND FRAMEWORK}

The issue of university underfunding in Nigeria is deeply rooted in the social, economic and political structures of the society as exemplified in the African political economy model. The model focuses on how political and economic forces shape the contexts within which Nigerian universities carry out their primary functions of teaching and research. It helps to explain the specific political, economic and social matrix of the present environment in Nigeria, whereby economic depression, political instability and cuts in government expenditure, all impact on the university system. The political economy model sees the different structures in the society, including the economic, political, social structures and the belief system as interacting and interdependent. Thus, the university system which is also a sub-sector is subjected to the influence of the superstructure which is the economic system (Aina, 2007).

The human capital theorists advocate for private support from parents / students and the other stakeholders, because education is both a government and private investment. This, according to the human capital theorists is vital in sustaining the finances of universities and in increasing economic growth rates. The model explains that people gain productivity by further training and the rates of return on these investments for both government and private individuals are very profitable, consequently both government and private individuals must finance education (Barr, 2004).

The Resource - Based model is adopted for this study as a strategy for sustaining financing of universities. This is because in Nigerian universities are weak in terms of budgeting, determination of operational costs and revenue generation. There is therefore a need to develop a logical framework that seeks to capture the major operations of the institutions and the resource flows to support them. The model creates the opportunity for all units in the university to be financially well structured and transparent. It enables them strive to achieve and maintain financial balance, while they are constantly aware of the resource implications of their programmes and activities and prepare for associated challenges. The model is dynamic for determining over time, the quantum of resources that a university requires within a particular time frame and consciously strategize on the ways to raise such funding so that they become less subject to the vagaries of the fluctuations in the fortunes and resources of its owners and the operating environment (Bamiro and Adedeji, 2010).

\section{CONCLUSION}

The various modes of funding federal universities in Nigeria were examined in this paper, with a view to assessing their adequacy and effectiveness. The implications of underfunding on university performance were identified and alternative modes of funding the system were proffered. The study revealed that although the federal government provides about 90 percent of university funds but due to economic, social and political depression, it has been unable to successfully finance the system. In response to this development, federal universities have devised their survival strategies by embarking on income generating ventures. Some of these ventures have conflicting effects on the major focus of the universities and they have also not been able to generate sufficient income for running the system. Consequently, the universities experience chronic underfunding which has impacted on their performance and their potentials to act as instruments of development.

The universities need to be opened to innovations and more pragmatic strategies in sourcing for nongovernment funds. Occasioned by this, alternatives modes of funding the universities were advocated in this paper. The African political economy model was used in explaining the financial state of Nigerian universities; the human capital theory was used to support the arguments in favour of multiple forms of cost-sharing since university is both a private and government investment and the Resource-Based Model was recommended for sustaining financing of universities because of its ability to determine the quantum of resources that a university requires within a frame of time and strategize on the ways to raise such funds so that the system would be less dependent on government. 
Arising from this, the study recommended the need for universities to network and collaborate with the productive sector for income generation and for the development of pragmatic measures needed in ensuring that tuition fees is introduced at all levels of study in the various federal universities.

\section{AUTHOR INFORMATION}

Christiana, O. Ogbogu lectures Public Administration in Obafemi Awolowo University, Nigeria. Her doctorate degree dissertation evaluated the labour input of females in Nigerian public universities. Her research work focuses on: Higher educational administration, gender analysis in cross cutting issues in Public Administration and human resource management. E-mail: cogbogu@oauife.edu.ng

\section{REFERENCES}

1. Adedeji, S.O. (2002). The cost and financing of education in Nigeria: The historical perspective. A paper presented at the forum on cost and financing of Education in Nigeria. Education Sector Analysis (ESA) Abuja, Nigeria.

2. Adeniyi, P.O. (2008). Repositioning Nigerian Universities for national sustainable development. A paper presented at the $10^{\text {th }}$ Iju Quarterly Public Affairs forum series, Ondo state, Nigeria.

3. Aina, O. I and Alaba, K. (1996). Strange bedfellows: Academic and non-academics in university governance. Research Report submitted to Social Science Council of Nigeria.

4. Aina, O.I. (2007). Alternative modes of financing Higher education in Nigeria and implications for university governance. In Babalola, J.B. and Emunemu B.O. (Eds.)Issues in higher education: Research evidence from sub-Saharan African. Bolabay Publications.

5. Aina, T.A. (2010). Beyond Reforms: The politics of higher education transformation in Africa. African studies Review 53(1) 22-40.

6. Ajayi, T. and Alani, R. (1996). A study on cost recovery in Nigerian university education: Issues of quality, access and equity. Financial Report Accra. Association of African universities. (AAU).

7. Akintoye, I.R. (2008). Optimizing output from Tertiary educational institutions via adequate funding: A lesson from Nigeria. International Research Journal of finance and economics. Vol. 4,359 -368.

8. Bamiro, O.A. and Adedeji , O.S. (2010). Sustainable financing of higher education in Nigeria. Ibadan: Ibadan University Press.

9. Babalola, J.B., Okunnola P.O., Adeyemi S.O. and Ibekwe, M.E. (1996). Cost and financing of university Education in Africa: The Nigerian experience. Revised Research Report. No. 4. Association of African universities.

10. Barr, N. (2004). Higher education funding. Oxford Review of Economic Policy, Vol. 20(2), 264-283.

11. Ejiogu, A.M. (1986). Landmarks in Educational Development in Nigeria. Lagos: Joja Educational Research and Publishers.

12. Ekundayo, H. T. and Ajayi, I. A. (2009). Towards effective management of university education in Nigeria. International NGO Journal. Vol. 4 (8) 342 - 347).

13. Fafunwa, A.B. (1971). A history of Higher Education in Nigeria Lagos. Macmillan and company (Nig) Ltd.

14. Hartnett, T. (2000). Financing trends and expenditure patterns in Nigerian Federal universities. : An update. Unpublished report: Washington D.C.: The World Bank.

15. Johnstone, O.B. (2003). Cost-sharing in Higher Education: Tuition, financial assistance and accessibility. Czech Sociological Review. Vol. 39(3), $351-374$.

16. Johnstone, O.B. (2005). The costs of higher education: Worldwide issues and trends for the1990s. Paper presented at the Pennsylvania state university sesquicentennial celebration.

17. National Universities Commission (2003). Twenty years of university education in Nigeria. Abuja, Nigeria.

18. Odebiyi, A.I and Aina, O.I. (1999). Alternative modes of financing higher education in Nigeria and implications for university governance. Final Report. Accra: association of African universities (AAU).

19. Okafor, N. (1971). The development of universities in Nigeria. London: Longman group Ltd.

20. Okebukola, P.A. (2002). The state of university Education in Nigeria. Abuja: National Universities Commission.

21. Saint, W., Hartnett, T. and Strassner, E. (2003). Higher Education in Nigeria: A status Report. Higher Education Policy Vol. 16, 259 - 281.

22. Yusuf, L.A. (2010). Resourceful financing management as Panacea for university sustainability in a depressed economy. Pakistan Journal of Social Sciences. Vol. 7(5): 347 - 350. 